\title{
Successful Homoeopathic Treatment of Phyllodes Tumour: A Case Study
}

\author{
Purnima Shukla ${ }^{1}$ Purak Misra ${ }^{2}$ Risabh Kumar Jain ${ }^{3}$ Rajiv Kumar Misra ${ }^{4}$ \\ 1 Senior consultant, Independent researcher, Former member of \\ ethical committee, CCRH (Under Ministry of AYUSH, Govt. of India), \\ New Delhi, India \\ 2 Department of Surgery, ESIC Medical College, NCR, Delhi, India \\ ${ }^{3}$ Department of Radiodiagnosis, Baba Raghav Das Medical College, \\ Gorakhpur, Uttar Pradesh, India \\ ${ }^{4}$ Department of Pathology, Baba Raghav Das Medical College, \\ Gorakhpur, Uttar Pradesh, India \\ Homœopathic Links 2021;34(2):130-140. \\ Address for correspondence Dr Purnima Shukla, MD (Homoeo), C4, \\ Shivalik, Malviya Nagar, New Delhi 110017, India \\ (e-mail: drpurnimashukla2019@gmail.com).
}

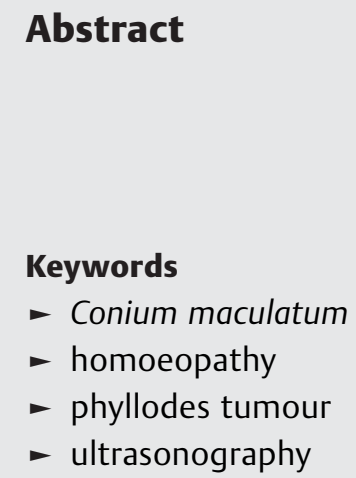

Phyllodes tumours (PTs) of the breast are rare biphasic fibroepithelial neoplasm. They have potentiality to recur and metastasise. Majority of them follow a benign clinical course. We have treated one patient suffering from PT at the out-patient department of Sri Ram Medical \& Homoeopathic Research Centre, Gorakhpur, India. After detailed case taking and repertorisation, first Conium maculatum and later on Phytolacca decandra and Calcarea fluorica were prescribed on the basis of individualisation to treat the case. Outcomes were assessed clinically every month for subjective improvement and objectively by ultrasonography reports at every 6-month interval. Gradual improvement was noted over time. The case has been assessed with MONARCH Inventory, which shows 'definite' association between the medicine and the outcome.

\section{Introduction}

Phyllodes tumour (PT) of the breast was described properly in 1838 , by Johannes Muller. He had given the term cystosarcoma phyllodes. But the tumours are rarely cystic and majority of them are benign. The World Health Organization has preferred the term 'phyllodes tumour' to denote this condition. ${ }^{1}$ Other synonyms are 'phyllodes sarcoma', 'serocystic disease of brodie' and 'benign cystosarcoma.. ${ }^{2}$ PTs are made up of a mixture of cells from connective tissue and the epithelium tissue layer lining the breast. They grow in a leaflike pattern, hence they get their name from a Greek word that means 'leaf like'. They sometimes degenerate histologically into sarcomatous lesions that lack an epithelial component. Depending on histological features including stromal cellularity, infiltration at the tumour's edge and mitotic activity, PT can be divided into following types: non-cancerous (benign, 50-60\%); borderline tumours; and cancerous (malignant, 20-25\%). 3,4 Of all female breast tumours, PTs are 0.3 to $0.5 \%$. The incidence of PT is $\sim 2.1$ per million. ${ }^{5}$ Mostly, they are found in women of 35 to 55 years of age. They are rare in adolescents and elderly women. ${ }^{6}$ No etiologic or predisposing factors have been associated with PTs, with the exception of Li-Fraumeni syndrome, a rare autosomal dominant condition that is characterised by the development of multiple tumours. ${ }^{7}$ The most common symptom is usually a firm palpable mass in the breast. The lump may grow quickly over a few weeks or months. If left untreated, the lump may cause a bulge in the breast and very occasionally the skin over the lump may ulcerate. Fine needle aspiration cytology/needle-core biopsy results when combined with imaging have good diagnostic sensitivity. ${ }^{8} \mathrm{Com}-$ monly, wide local excision is the treatment. But a very high percentage of surgeries despite wide excision has yielded incomplete excision margins that needed revision surgery. ${ }^{3}$

We had taken up a project, ${ }^{9}$ 'Homoeopathic Management of Benign Neoplastic Lesions of Breast: An Evidence Based Study', at 'Purti Priya Memorial', Sri Ram Medical \& Homoeopathic Research Centre, Gorakhpur, India. This project had continued for 3 years and had included 109 cases of benign
DOI https://doi.org/ 10.1055/s-0040-1717133. ISSN 1019-2050. (c) 2021. Thieme. All rights reserved.

Thieme Medical and Scientific Publishers Pvt. Ltd., A-12, 2nd Floor, Sector 2,

Noida-201301 UP, India 


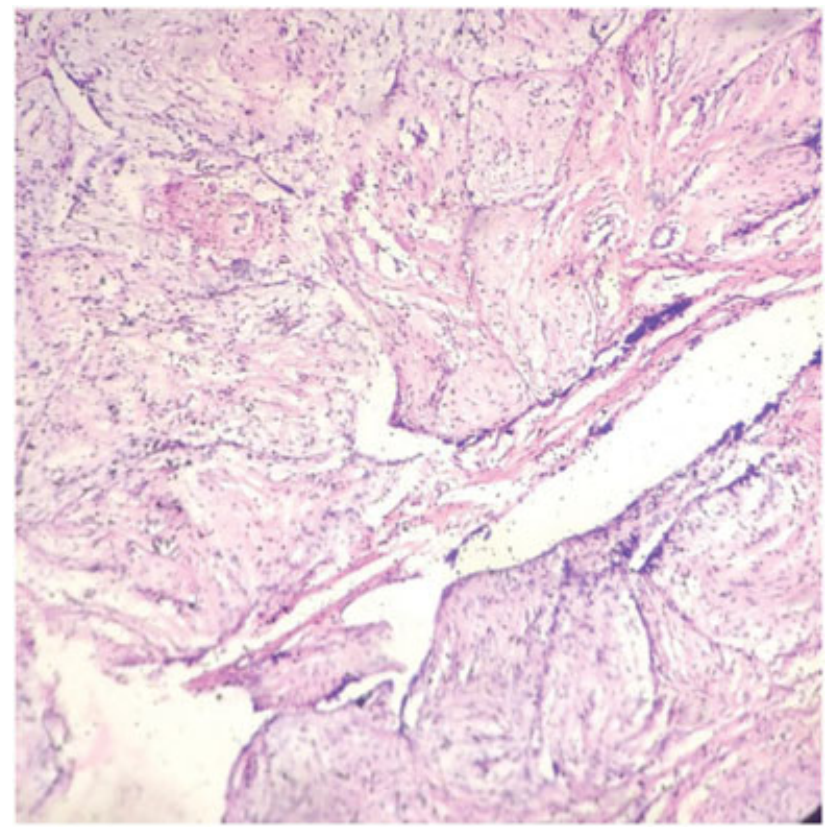

Fig. 1 Histopathology of phyllodes tumour of the patient; H \& E x 80.

neoplastic lesions of breast, comprising of 70 cases of fibroadenoma, 29 cases of fibroadenosis, 5 cases of fibrocystic adenoma, 1 case of lipoma, 2 cases of duct papilloma, 1 case of PT and one case of fibroadenoma with fibroadenosis. The data and results before and after treatment were obtained by Department of Radiology and Pathology, Baba Raghav Das Medical College, Gorakhpur, Uttar Pradesh (Government institution, recognised by Medical Council of India). Hence, the integrity and accuracy of the results were well monitored by the concerned departmental faculty. The single case of PT, which had shown persistent improvement over time as demonstrated sonologically, has been presented here. It has been assessed using MONARCH Inventory ${ }^{10}$ as well, which shows 'definite' association between the medicine and the outcome (definite: $\geq 9$; probable 5-8; possible 1-4; and doubtful $\leq 0$ ).

\section{Case Report}

Case: S, 22-year-old, female, married, housewife presented with painful lumps and itching in both the breasts for past 2 years. Pain as well as itching would become intolerable before menses. No remarkable past illness was noted. Regarding family history, her father had tuberculosis earlier and her mother had uterine fibroid; both are alive. No striking features in her physical generalities were noted except that she suffered from bloody leucorrhoea frequently for the last 1 year. She was nullipara and her menses were normal. On further enquiry, it was revealed that she had some cough for last few months, which returned only when she lied down. She said that she was having anxiety about her future as she was advised earlier for surgical removal of the lump. She was very superstitious, which was evident from her narration. She was talking about evil powers that were trying to destroy her and somebody was using these evil powers against her. Consequently, she said that she was confused about what to do and what not to do regarding her disease, her future, etc.

Clinical examination: On local examination, it was found that the right breast was wholly indurated and the lump was a huge one. There was a grape-size lump in the left breast. It was stony hard and limited to lower outer quadrant only. Also, there was tenderness in both the mammae. No axillary or cervical lymph gland was palpable. On enquiry, it was revealed that she was suffering from this for the last 1 year.

Investigation: Tru-Cut biopsy confirmed that it was a case of PT ( - Fig. 1); ultrasonography (USG) report done 3 days later (-Figs. 2 and $\mathbf{3}$ ) shows size of the lesions as follows. Right breast: $103.9 \mathrm{~mm} \times 34.3 \mathrm{~mm}$; shape, oval; margins, circumscribed and regular; echo pattern, hypoechoic; vascularity, hypovascular-BI-RADS 3. Left breast: $9.4 \mathrm{~mm} \times 8.6 \mathrm{~mm}$.

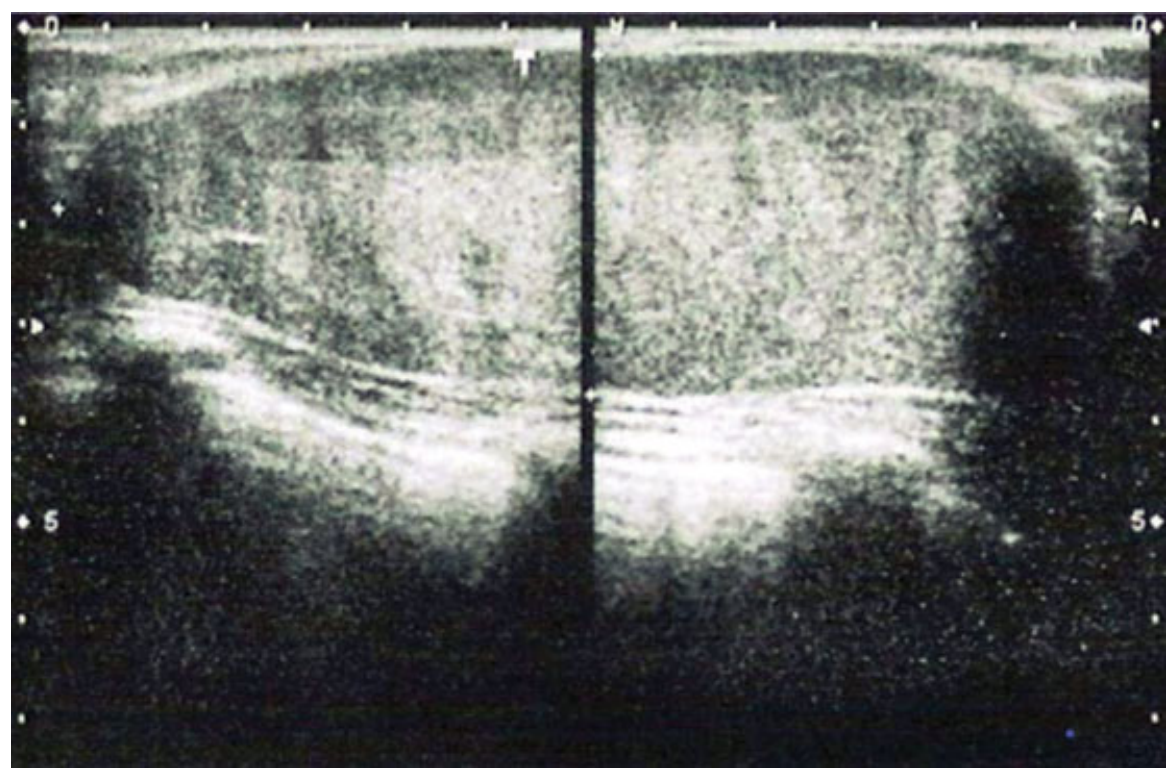

Fig. 2 Ultrasonography scan of first visit (measurement of tumours: right breast, $103.9 \mathrm{~mm} \times 34.3 \mathrm{~mm}$; left breast, $9.4 \mathrm{~mm} \times 8.6 \mathrm{~mm}$ ). 


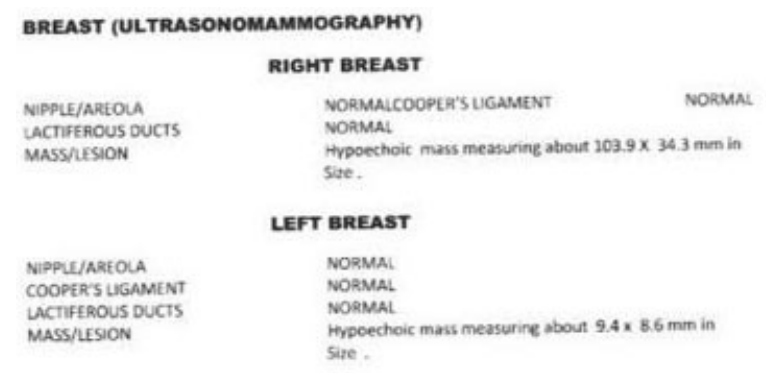

IMPRESSION Bilateral FIbroadenoma breast (PHYLLODES)

Fig. 3 Ultrasonography report of first visit (measurement of tumours: right breast, $103.9 \mathrm{~mm} \times 34.3 \mathrm{~mm}$; left breast, $9.4 \mathrm{~mm} \times 8.6 \mathrm{~mm})$.

Vaginal swab test was done to detect any bacterial infection, which was not present. (We had planned for trans-vaginal USG, but was not required as the complaint of bloody leucorrhoea ameliorated gradually and subsided completely after sixth visit.)

Guidelines for prescription: She had confusion regarding the decisions to be taken, and was anxious about her future. She was bearing some superstitious beliefs. Her both breasts were indurated and itched much, which always aggravated before menses. She had mild cough only while lying down. Often, she had bloody leucorrhoea. On the basis of this totality, repertorisation ${ }^{11}$ was done (-Tables $\mathbf{1}$ and $\mathbf{2}$ ).

Prescription: She was prescribed with Conium maculatum 200C, unit dose, to be taken next morning in empty stomach.

Follow-up and assessment: She returned every month for regular follow-up for next 3 years. Remarkable followups are tabulated (-Table $\mathbf{3}$ ). By the next visit, there was a remarkable change in her left breast; the lump was almost impalpable. She also had relief in pain, tenderness and itching of mammae. Later on, due to the standstill condition of the case, even after repetition of the previous medicine, we went for further revision of the case. Some new symp- toms like excoriation and painful cracks on the nipple were seen. Also, it was found that she was having general aggravation at night in cold. New totality was framed. Her right breast was sensitive and painful, which aggravated during menses. Her nipples were excoriated with painful cracks. She never felt well at night. Cold exposure was also not agreeable. Repertorisation (-Tables 4 and 5) indicated another medicine this time. After careful consultation with the Materia Medica, ${ }^{12,13}$ she was prescribed with Phytolacca decandra 200C, unit dose. She was gradually getting better. By the end of the second year, no more anxiety or confusion was noted in her. Remarkable improvement was noted in the breast tumours as well. At this point of time, her complaints had come to a standstill. Though she had improved a lot earlier, no further progression was happening. There was no tumour in her left breast anymore. Tumour in the right breast also reduced in size but hardness was remaining. Excoriation as well as cracks were completely healed up. During her menses, there was no pain in her mammae anymore. Then, again complete case taking was done and it was found that there were some disturbances in her family environment that acted as obstacle in her treatment. Apart from her mental symptoms, some physical general symptoms like sensation of heat and flushes of heat alternating with chill were found. Consequently, we gathered another totality of symptoms. She was anxious about her own health. She feared mice, misfortune and poverty. She did not like warm weather. She had heat flushes, alternating with chills occasionally. She had desire for pickles. Her right breast was sensitive as well as indurated. Repertorisation ( - Tables 6 and 7) indicated Calcarea fluorica. We prescribed Calcarea fluorica 200C, unit dose. She was getting better gradually. Last time she visited us, we palpated two small potato-sized lesion in the same part of the breast instead of the solitary lesion, which was palpated earlier. But by the end of the third year, she migrated to some other city, and could not visit us further. Before leaving the town, she was demonstrated regarding the technique of breast self-examination and was provided with pictorial guidelines of the same. By the sixth month we were informed over telephone that she was not having any

Table 1 Rubrics enumerated for repertorisation (first visit)

\begin{tabular}{|l|l|l|}
\hline S. No. & Rubrics & Number of medicines \\
\hline 1 & MIND-CONFUSION of mind & 571 \\
\hline 2 & MIND-ANXIETY-future, about & 200 \\
\hline 3 & MIND-SUPERSTITIOUS & 22 \\
\hline 4 & CHEST-INDURATION-Mammae-right & 10 \\
\hline 5 & CHEST-INDURATION-Mammae-left & 9 \\
\hline 6 & CHEST-ITCHING-Mammae & 43 \\
\hline 7 & CHEST-MAMMAE; complaints of-menses; before & 19 \\
\hline 8 & COUGH-LYING DOWN aggravated & 35 \\
\hline 9 & FEMALE GENITALIA/SEX-LEUCORRHOEA-bloody & 88 \\
\hline
\end{tabular}


Table 2 Repertorisation sheet as obtained by using the rubrics of $\mathbf{- T a b l e} 1$

\begin{tabular}{|l|l|l|l|l|l|l|l|l|l|l|}
\hline Medicine & Con. & Calc. & Lyc. & Sil. & Ars. & Carb-v. & Rhus-t. & Arg-n. & Caust. & Kali-c. \\
\hline Score & $9 / 20$ & $7 / 11$ & $6 / 8$ & $5 / 11$ & $5 / 8$ & $5 / 8$ & $5 / 8$ & $5 / 7$ & $5 / 7$ & $5 / 7$ \\
\hline 1 & 2 & 3 & 2 & 3 & 2 & 3 & 3 & 2 & 1 & 2 \\
\hline 2 & 2 & 3 & - & 2 & 1 & 1 & 2 & 1 & 2 & 1 \\
\hline 3 & 2 & - & - & - & - & - & 1 & 1 & - & - \\
\hline 4 & 3 & - & 1 & - & - & - & - & - & - & - \\
\hline 5 & 3 & 1 & - & 3 & - & - & - & - & - & - \\
\hline 6 & 3 & 1 & 1 & 1 & 1 & 1 & 1 & - & 2 & 2 \\
\hline 7 & 2 & 1 & 1 & - & - & - & - & - & - & 1 \\
\hline 8 & 1 & 1 & 1 & - & 2 & 1 & 1 & 1 & 1 \\
\hline 9 & 2 & 1 & 2 & 2 & 2 & 2 & - & 2 & 1 \\
\hline
\end{tabular}

Table 3 Follow-up of the case

\begin{tabular}{|c|c|c|c|}
\hline Date & Complaint & USG report & Prescription \\
\hline Third follow-up & $\begin{array}{l}\text { Itching was relieved; other complaints were } \\
\text { persisting; on examination, lesions were found } \\
\text { to be less tender }\end{array}$ & Not done & $\begin{array}{l}\text { Conium maculatum } \\
200,1 \text { dose }\end{array}$ \\
\hline Sixth follow-up & $\begin{array}{l}\text { Anxiety was much better; sensitive of breasts } \\
\text { were persisting; leucorrhoea, present occa- } \\
\text { sionally, no more 'bloody' }\end{array}$ & $\begin{array}{l}\text { Right breast (Rtb) } \\
95.5 \mathrm{~mm} \times 46.6 \mathrm{~mm} \text {; left } \\
\text { breast (Ltb) within nor- } \\
\text { mal limit (WNL; - Figs. } 4 \\
\text { and 5) }\end{array}$ & Placebo \\
\hline 10th follow-up & $\begin{array}{l}\text { Excoriation and cracks on the nipples were new } \\
\text { symptoms to appear }\end{array}$ & Not done & $\begin{array}{l}\text { Phytolacca decandra } \\
200,1 \text { dose }\end{array}$ \\
\hline 12th follow-up & $\begin{array}{l}\text { Excoriation and cracks were much relieved; } \\
\text { firmness of the lesion was persisting }\end{array}$ & $\begin{array}{l}\text { Rtb } \\
40.4 \mathrm{~mm} \times 32.5 \mathrm{~mm} \times- \\
28.3 \mathrm{~mm} ; \text { Ltb WNL } \\
(\text { - Figs. } 6 \text { and 7) }\end{array}$ & Placebo \\
\hline 15th follow-up & Almost similar state was persisting & Not done & $\begin{array}{l}\text { Phytolacca decandra } \\
200,1 \text { dose }\end{array}$ \\
\hline 19th follow-up & $\begin{array}{l}\text { Lesions became less tender, less sensitive; no } \\
\text { excoriation, no cracks on the nipples }\end{array}$ & $\begin{array}{l}\text { Rtb } 25.8 \mathrm{~mm} \times 20.8 \mathrm{~mm} \\
(\mathbf{- F i g s . 8} \text { and } \mathbf{9})\end{array}$ & Placebo \\
\hline 23rd follow-up & $\begin{array}{l}\text { Anxiety returned somewhat; firmness was } \\
\text { same as before }\end{array}$ & Not done & Placebo \\
\hline 25th follow-up & $\begin{array}{l}\text { Anxiety got added with fearfulness; sensitivity } \\
\text { of right breast returned }\end{array}$ & $\begin{array}{l}\text { Rtb } 23.2 \mathrm{~mm} \times 20.8 \mathrm{~mm} \\
\text { (-Figs. } 10 \text { and 11) }\end{array}$ & $\begin{array}{l}\text { Calcarea fluorica } \\
200,1 \text { dose }\end{array}$ \\
\hline 28th follow-up & $\begin{array}{l}\text { Anxiety, fearfulness was still persisting; sensi- } \\
\text { tivity of right breast had improved to some } \\
\text { extent }\end{array}$ & Not done & Placebo \\
\hline 30th follow-up & $\begin{array}{l}\text { Two small potato-sized lesion was palpated at } \\
\text { the same location instead of solitary lesion } \\
\text { palpated earlier; sensitivity was reduced } \\
\text { further }\end{array}$ & $\begin{array}{l}\text { Rtb } 21 \mathrm{~mm} \times 18.7 \mathrm{~mm} \\
(=\text { Figs. } 12 \text { and 13) }\end{array}$ & $\begin{array}{l}\text { Calcarea fluorica } \\
200,1 \text { dose }\end{array}$ \\
\hline
\end{tabular}

complaint and that the swelling of her right breast had subsided entirely. She had visited local gynaecologist, where she was informed that on palpation of the breasts nothing abnormal was there, hence USG was also not required. Accordingly, our patient did not opt for any investigation thereafter. Even after repeated request for investigation from our side, she is not ready to undergo one.

\section{Patient perspective}

According to her, she is much better than before. No breast lump can be palpated any more though she undertakes 


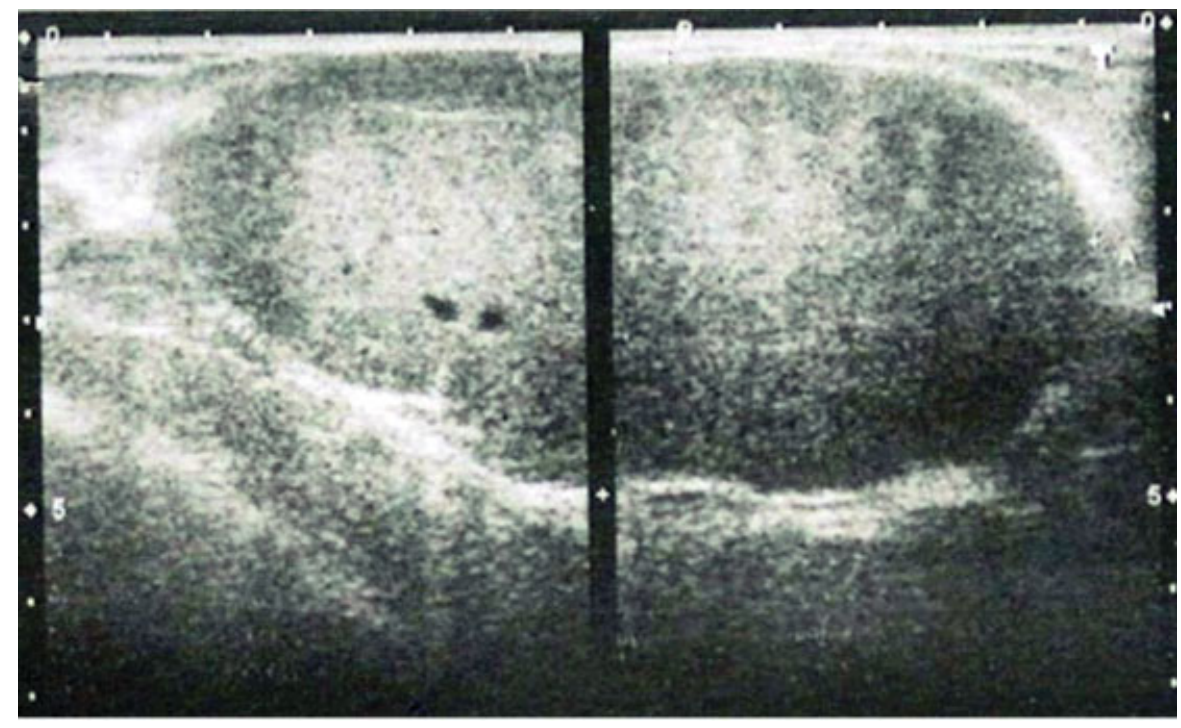

Fig. 4 Ultrasonography scan of sixth follow-up (measurement of tumour: right breast, $95.5 \mathrm{~mm} \times 46.6 \mathrm{~mm}$; left breast, within normal limit).

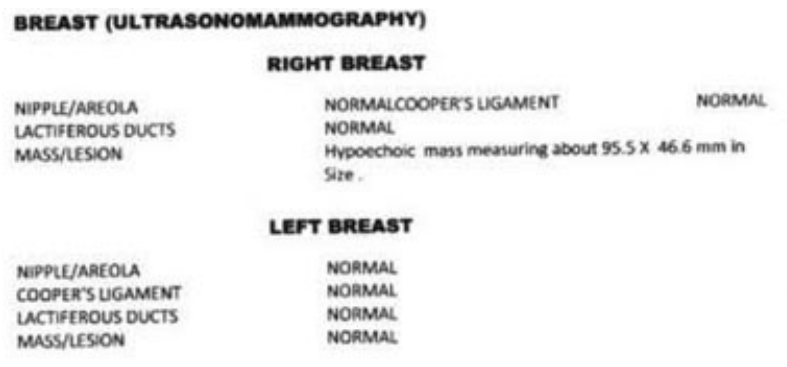

IMPRESSION

FUC of Bllateral Fibroadenoma breast (PWYLODEs)

Fig. 5 Ultrasonography report of sixth follow-up (measurement of tumour: right breast, $95.5 \mathrm{~mm} \times 46.6 \mathrm{~mm}$; left breast, within normal limit).

'breast self-examination' every month. At the same time, the quality of her daily living has also improved a lot. So, she is not willing to have any more follow-up investigation.

\section{Discussion}

This case was extracted from the project ${ }^{9}$ done by the authors at 'Purti Priya Memorial', Sri Ram Medical \& Homoeopathic Research Centre, Gorakhpur, India. Written informed consent by the patient regarding publishing was obtained prior to approaching for publication. Here, the final selection of the medicine was done on the basis of the standard homoeopathic guidelines at every instance. In modern medicine, the only treatment for PT is its surgical removal. Moreover, there may again be the recurrence of the disease. ${ }^{14}$ Also, surgery cannot be done in every patient, either because of advanced pathology or some other systemic illness of the patient or sometimes because the patient is not ready for the surgery due to mental anxiety. But, in homoeopathy, 'there are no diseases, but sick people, ${ }^{15}$ so, whatever may be the systemic illness or mental anxiety or any other type of situation, if signs and symptoms are present then treatment can be done. ${ }^{16}$ Though it has been said that women of age 35 to 55 years are commonly affected, ${ }^{6}$ our case was aged only 22 years. In the case described above, after repertorisation, a group of medicines were found, among which Conium maculatum, Calcarea carbonica, Lycopodium clavatum and Silicea were the leading remedies. After consultation of Materia Medica, Conium maculatum was prescribed on the basis of totality of the symptoms. ${ }^{12,13}$ But with the progression of time, some new symptoms were found that were not found earlier, like there were excoriation and cracks on the nipple, and all the complaints aggravated at night and in cold. Hence, again repertorisation was done and Phytolacca decandra was prescribed, which did well, and maximum physical complaints were relieved. Due to some disturbances in her family, the patient had some mental symptoms. We had considered these disturbances as obstacles in her treatment. Hence, again, fresh repertorisation was done including her present mental complaints. On the basis of that, Calcarea fluorica was prescribed. By the time of last follow-up, the previously examined single lesion was palpated to be two small potatosized lesion. One repetition of the same remedy was done. After that the patient had to travel to another city but we were informed later on over telephone that she got complete relief from this tumour. Dose, in terms of potency as well as repetition, was also individualised on the judgement of susceptibility of the patient. Follow-ups were done according to the classical homoeopathic guidelines. 'Definite' association between the medicine and the outcome has been found while assessing the case using MONARCH Inventory (-Table 8). For domain 1 of the inventory, it is clear that the main symptom improved gradually as evident from the available USG reports. By the end of third month (third follow-up as well) of treatment, she started feeling better as far as her sensations are concerned. Next (sixth follow-up) 


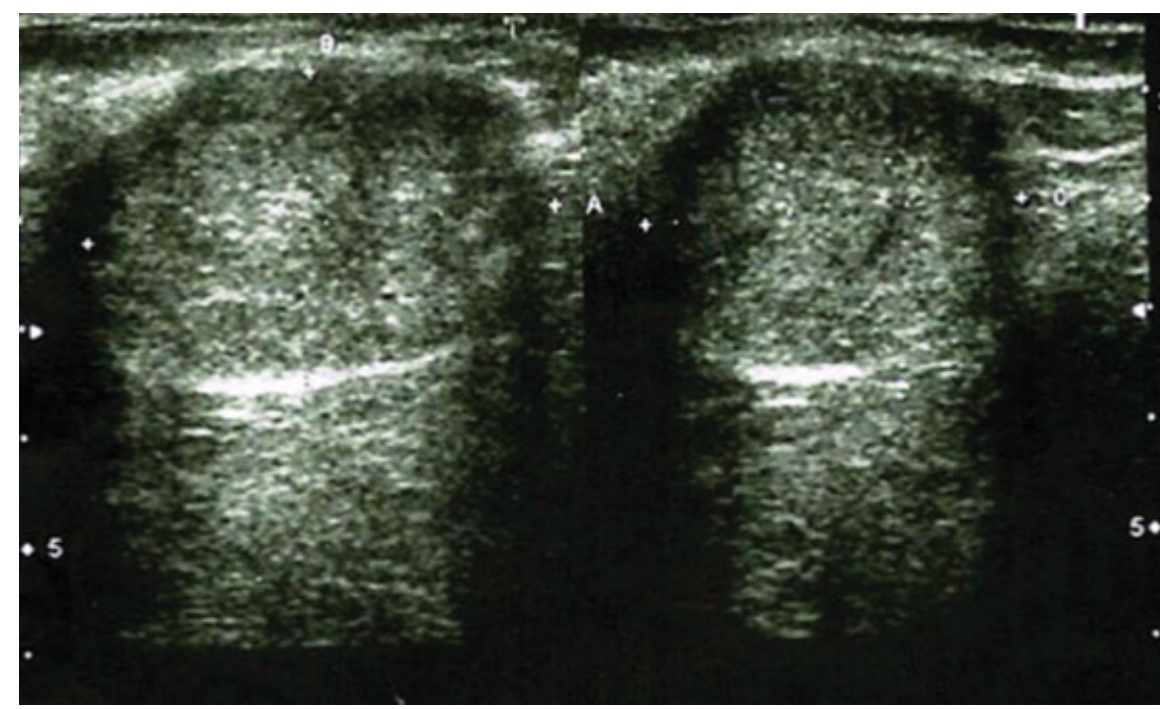

Fig. 6 Ultrasonography scan of 12th follow-up (measurement of tumour: right breast, $40.4 \mathrm{~mm} \times 32.5 \mathrm{~mm} \times 28.3 \mathrm{~mm}$; left breast, within normal limit).

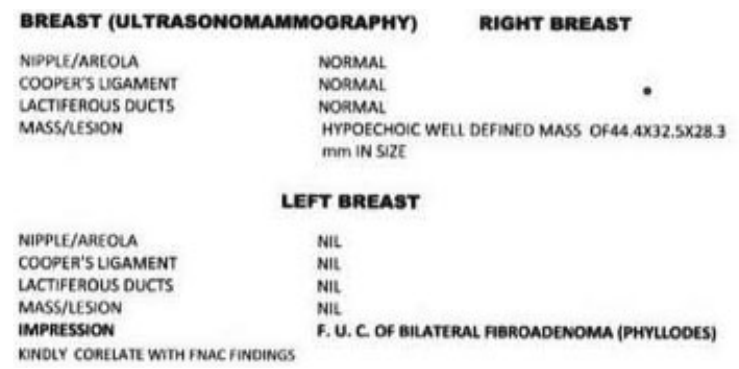

Fig. 7 Ultrasonography report of 12 th follow-up (measurement of tumour: right breast, $40.4 \mathrm{~mm} \times 32.5 \mathrm{~mm} \times 28.3 \mathrm{~mm}$; left breast, within normal limit).

USG report has shown regression of the lesion. By the end of $2 \frac{1}{2}$ years, the lesion has reduced to one-fifth of its initial size, when she was still under treatment only. So, for domain 2 , we can consider that the clinical improvement has occurred within a plausible time frame relative to the medicine intake. For domain 3, we have not encountered any homoeopathic aggravation. During the course of treatment, the patient improved in terms of her leucorrhoea and some mental symptoms. Therefore, as per domain 4 , we can consider that the effect of medicine has encompassed more than the main symptom or condition. Along with the improvement of the PT, the patient improved in mental aspects too, which was reflected in her expressions at emotional and behavioural aspects. So, for domain 5 , we can state that the overall well-being improved. Regarding domains $6 \mathrm{~A}$ and $6 \mathrm{~B}$, we can observe in the case that, at the 10th visit, excoriation and cracks on the nipples appear as new symptoms, whereas the induration of deeper breast tissues (in the form of PT) has reduced to a great extent. For domain 7 , none of the 'old symptoms' were found to reappear during the course of improvement. We could not ascertain any alternative causes

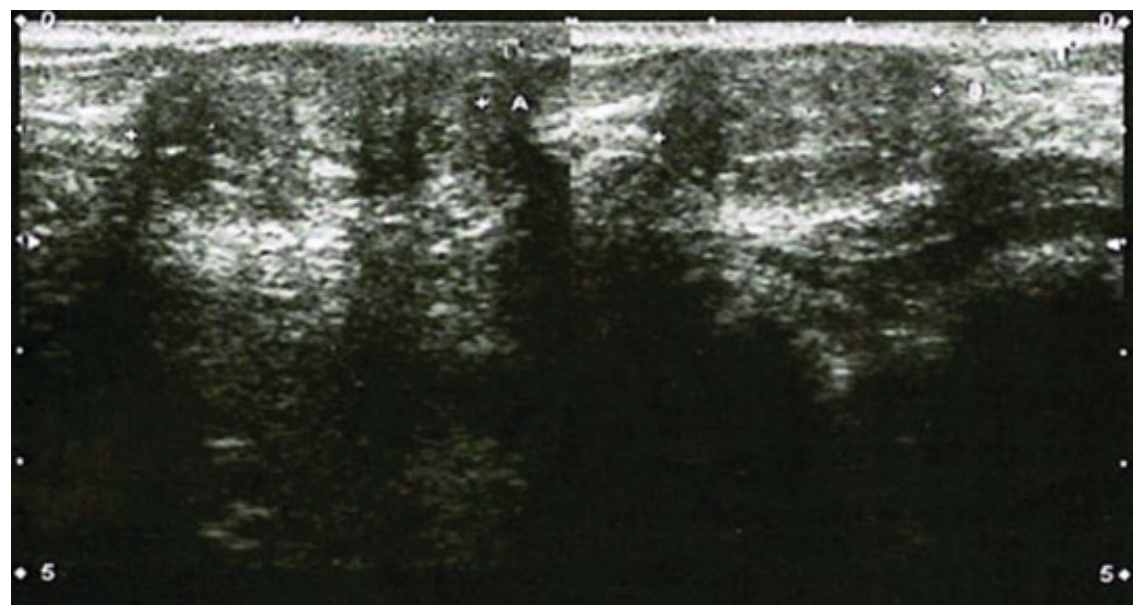

Fig. 8 Ultrasonography scan of 19th follow-up (measurement of tumour: right breast, $25.8 \mathrm{~mm} \times 20.8 \mathrm{~mm}$; left breast, within normal limit). 


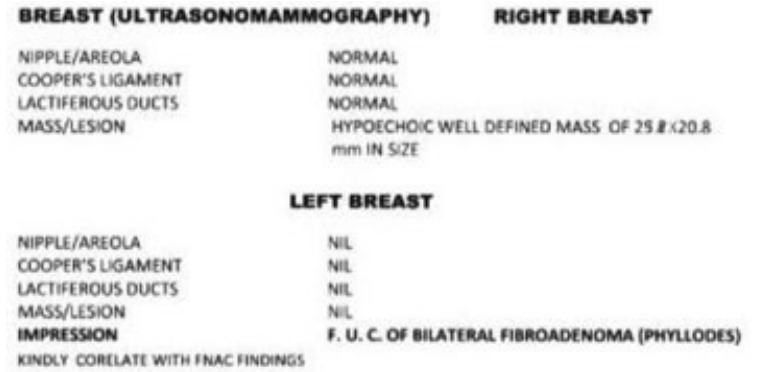

Fig. 9 Ultrasonography report of 19th follow-up (measurement of tumour: right breast, $25.8 \mathrm{~mm} \times 20.8 \mathrm{~mm}$; left breast, within normal limit).

that could have produced the improvement, as regarding domain 8. Regarding domain 9, the objective evidence of USG reports, done at regular intervals, confirms the health improvement. Domain 10 is not applicable in this case, as this domain is related to reproducibility. The limitation of this study, which is also a very important issue, is non-availability of latest investigation report to demand complete disappearance of the lump.

In a case of PT, where evidences of conservative treatment are lacking, it is common for the patients and the surgeons to take surgical help. This case demonstrates that not all apparently surgical cases are truly surgical. Hence, we arrived at a conclusion that if complete case taking is done including all the spheres of the patient and a proper followup is done, then we can cure even the most so-called difficult case, but for that a good skill and a lot of patience is needed.

In few case studies published so far, PTs were treated surgically. ${ }^{17,18}$ In one retrospective study, patients undergoing surgery with or without adjuvant radiotherapy (RT) for malignant PTs of the breast were analysed to find out the treatment outcome and risk factors for recurrence. ${ }^{14}$ In one

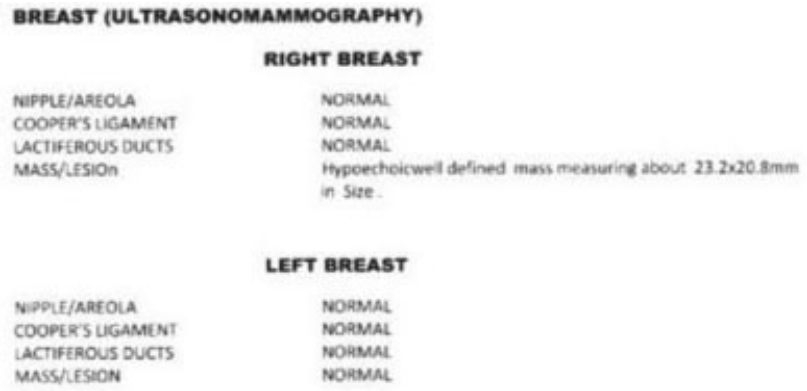

IMPRESSION FUC of bilateral FIbroadenoma (phylloides)

Fig. 11 Ultrasonography report of 25th follow-up (measurement of tumour: right breast, $23.2 \mathrm{~mm} \times 20.8 \mathrm{~mm}$; left breast, within normal limit).

study, chemotherapy and RT without surgical intervention were not found to be effective. ${ }^{19}$ Another study has shown malignant/borderline PTs that do not have poor histologic features have favourable prognosis after surgical resection. In this case, a 10 -year disease-specific survival is $100 \%$. Uniformly poor pathologic features, when present, predict a poor prognosis. The authors suggest that efforts should be directed towards new treatment approaches for these tumours. ${ }^{20}$ There is no published evidence regarding the use of only conservative treatment in the conventional therapy. At the same time, no published case has been identified that is treated with homoeopathic medicines. In this regard, this case is the first one. Furthermore, this case demonstrates how a so-called surgical case can be managed conservatively, in a harmless way, within a tolerable period of time. Most vital limitation of the case is the lack of triple

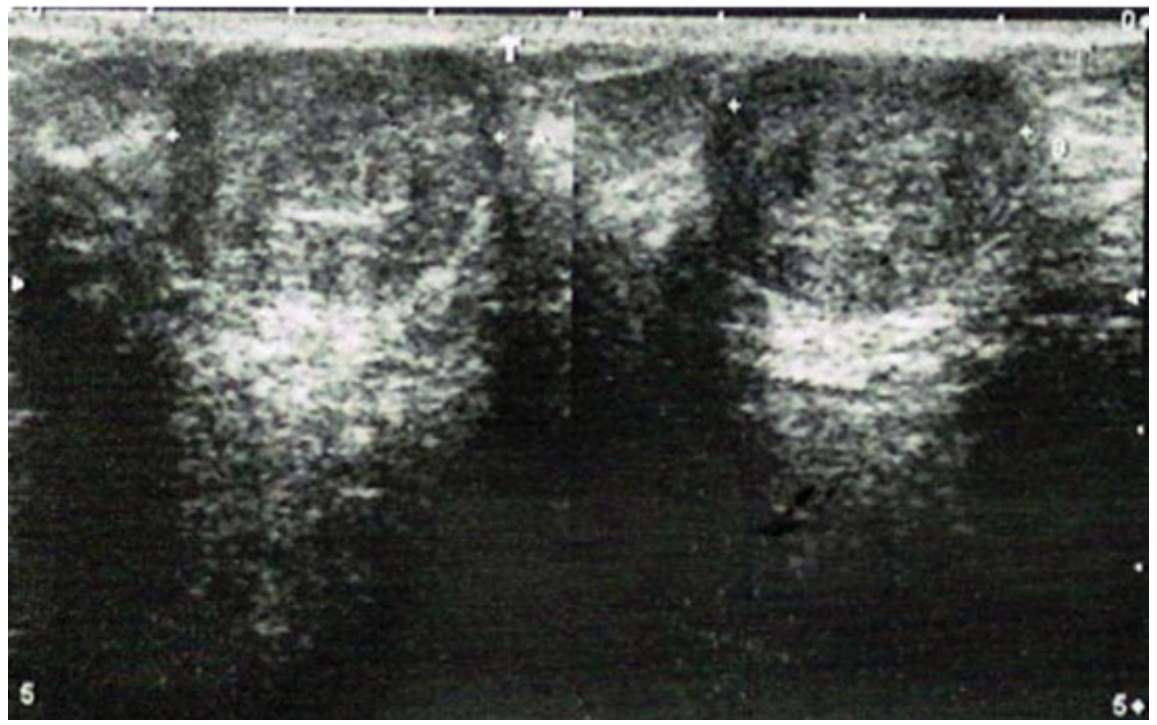

Fig. 10 Ultrasonography scan of 25th follow-up (measurement of tumour: right breast, $23.2 \mathrm{~mm} \times 20.8 \mathrm{~mm}$; left breast, within normal limit). 


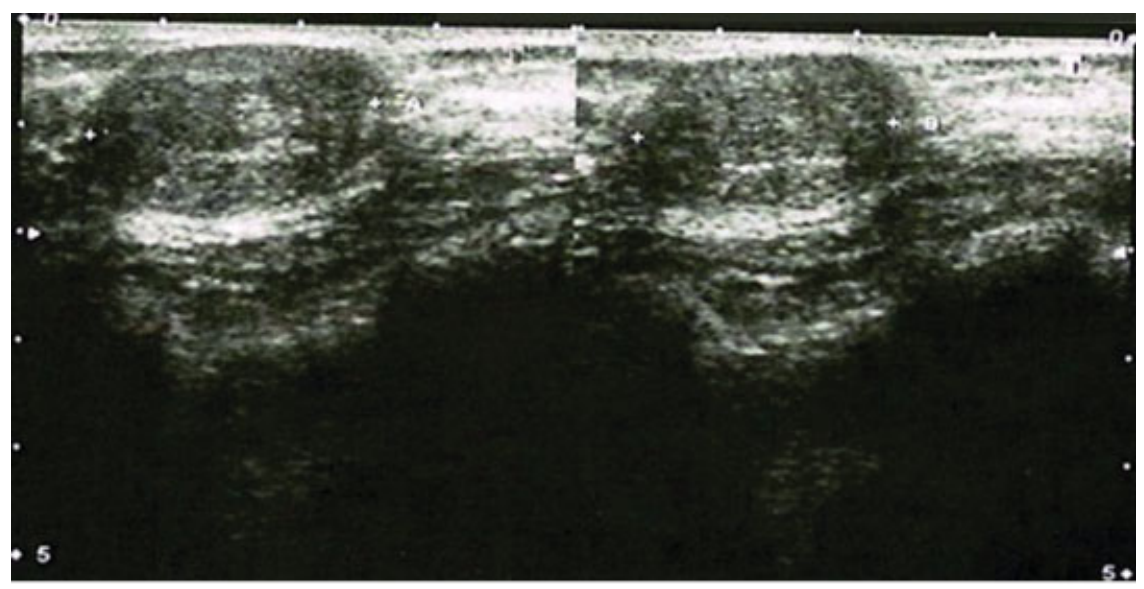

Fig. 12 Ultrasonography scan of 30th follow-up (measurement of tumour: right breast, $21.0 \mathrm{~mm} \times 18.7 \mathrm{~mm}$; left breast, within normal limit).

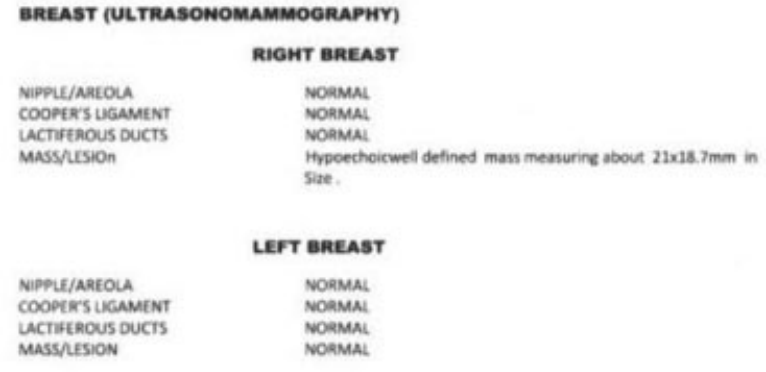

IMPression FUC of bilateral Fibroadenoma (phylloides)

Fig. 13 Ultrasonography report of 30th follow-up (measurement of tumour: right breast, $21.0 \mathrm{~mm} \times 18.7 \mathrm{~mm}$; left breast, within normal limit).

assessment test that was needed to be done towards the end of the treatment. At the same time, a scale assessing subjectively the quality of life of the patient before and after treatment could be applied. We will be adhering to such details in our future projects.

According to homoeopathic point of view, 'all curable sicknesses make themselves known to the intelligent physician in form of signs and symptoms' (aphorism 14). ${ }^{16}$ Moreover, we get some literature in the texts of Dr J.C. Burnett regarding the treatment of such cases, where he had successfully cured breast tumour of size corresponding approximately to that of a large hen's egg and his big fist. ${ }^{21,22}$ Hence, a successful curative approach can be made by homoeopathy in such cases also. The given case can serve as the first step towards evidence-based research. As the results of the homoeopathic treatment are promising, later on, observational trials can be undertaken. As PT is a rare condition, studies with large sample size may not be plausible. But clinical trials can be approached with individualised homoeopathic medicines to assess the outcomes of the different pathological variations in the same individual. ${ }^{23,24}$ Multiple pathological variations in the same person are a matter of study that can be taken up in future, using suitable outcome assessing tools.

Table 4 Rubrics enumerated for repertorisation (10th follow-up)

\begin{tabular}{|l|l|l|}
\hline S. No. & Rubrics & Number of medicines \\
\hline 1 & CHEST-NODULES, sensitive-Mammae-painful & 3 \\
\hline 2 & CHEST-NODULES, sensitive-Mammae & 51 \\
\hline 3 & CHEST-PAIN-Mammae-menses-during-aggravated & 32 \\
\hline 4 & CHEST-EXCORIATION-Mammae-Nipples & 34 \\
\hline 5 & CHEST-TUMOURS-Mammae-fibrocystic & 4 \\
\hline 6 & CHEST-TUMOURS-Mammae-painful & 2 \\
\hline 7 & CHEST-CRACKS-Mammae-Nipples-painful & 4 \\
\hline 8 & GENERALS-COLD-aggravated & 301 \\
\hline 9 & GENERALS-NIGHT & 292 \\
\hline
\end{tabular}


138 Successful Homoeopathic Treatment of Phyllodes Tumour Shukla et al.

Table 5 Repertorisation sheet as obtained by using the rubrics of $\mathbf{- T a b l e} 4$

\begin{tabular}{|l|l|l|l|l|l|l|l|l|l|l|}
\hline Medicines & Phyt. & Phos. & Graph. & Puls. & Sil. & Nit-ac. & Merc. & Dulc. & Con. & Lyc. \\
\hline Score & $9 / 16$ & $7 / 13$ & $6 / 12$ & $6 / 11$ & $5 / 12$ & $5 / 11$ & $5 / 10$ & $5 / 9$ & $4 / 10$ & $4 / 9$ \\
\hline 1 & 1 & 1 & - & - & - & - & - & - & - & - \\
\hline 2 & 3 & 2 & 2 & 2 & 3 & 2 & 1 & 1 & 3 & 2 \\
\hline 3 & 2 & 2 & 1 & 2 & - & - & 2 & 1 & 2 & - \\
\hline 4 & 3 & 1 & 2 & 1 & 2 & 2 & 2 & 1 & - & 2 \\
\hline 5 & 1 & 1 & - & 1 & 1 & - & - & - & - & - \\
\hline 6 & 1 & - & - & - & - & - & - & - & - & - \\
\hline 7 & 1 & - & 1 & - & - & 1 & - & - & - & - \\
\hline 8 & 2 & 3 & 3 & 2 & 3 & 3 & 2 & 3 & 2 & 3 \\
\hline 9 & 2 & 3 & 3 & 3 & 3 & 3 & 3 & 3 & 3 & 2 \\
\hline
\end{tabular}

Table 6 Rubrics enumerated for repertorisation (25th follow-up)

\begin{tabular}{|l|l|l|}
\hline S. No. & Rubrics & Number of medicines \\
\hline 1 & MIND-ANXIETY-health; about-own health; one's & 85 \\
\hline 2 & MIND-FEAR-mice & 10 \\
\hline 3 & MIND-FEAR-misfortune, of & 121 \\
\hline 4 & MIND-FEAR-poverty, of & 65 \\
\hline 5 & GENERALS-HEAT-sensation of & 222 \\
\hline 6 & GENERALS-HEAT-flushes of-alternating with-chills & 23 \\
\hline 7 & GENERALS-FOOD and DRINKS-pickles-desire & 42 \\
\hline 8 & CHEST-INDURATION-Mammae & 65 \\
\hline 9 & CHEST-NODULES, sensitive-Mammae & 51 \\
\hline
\end{tabular}

Table 7 Repertorisation sheet as obtained by using the rubrics of - Table 6

\begin{tabular}{|l|l|l|l|l|l|l|l|l|l|l|}
\hline Medicines & Calc-f. & Ars. & Calc. & Puls. & Sep. & Sulph. & Sil. & Bry. & Merc. & Cupr. \\
\hline Score & $9 / 11$ & $8 / 12$ & $7 / 15$ & $7 / 12$ & $7 / 12$ & $7 / 12$ & $6 / 12$ & $6 / 10$ & $6 / 9$ & $6 / 8$ \\
\hline 1 & 1 & 3 & 2 & 2 & 2 & 1 & 1 & 1 & 1 & 1 \\
\hline 2 & 1 & - & 3 & 1 & 1 & - & - & - & - & 1 \\
\hline 3 & 1 & 1 & 2 & 2 & - & 1 & 1 & 1 & 2 & 1 \\
\hline 4 & 2 & 1 & 2 & 1 & 2 & 1 & 1 & 3 & 1 & - \\
\hline 5 & 2 & 1 & 2 & 3 & - & 3 & 3 & 1 & 2 & 2 \\
\hline 6 & 1 & 1 & 2 & - & 2 & - & - & - & - & - \\
\hline 7 & 1 & 1 & - & - & 2 & 2 & - & - & - & - \\
\hline 8 & 1 & 1 & 2 & 1 & 2 & 2 & 3 & 2 & 2 & 2 \\
\hline 9 & 1 & 3 & - & 2 & 1 & 2 & 3 & 2 & 1 & 1 \\
\hline
\end{tabular}

Table 8 Analysis of the case according to MONARCH Inventory

\begin{tabular}{|l|l|l|l|l|}
\hline & Domains & Yes & No & Not sure or N/A \\
\hline 1. & $\begin{array}{l}\text { Was there an improvement in the main } \\
\text { symptom or condition for which the homoeo- } \\
\text { pathic medicine was prescribed? }\end{array}$ & +2 & & \\
\hline
\end{tabular}


Table 8 (Continued)

\begin{tabular}{|c|c|c|c|c|}
\hline & Domains & Yes & No & Not sure or $N / A$ \\
\hline 2. & $\begin{array}{l}\text { Did the clinical improvement occur within a } \\
\text { plausible time frame relative to the medicine } \\
\text { intake? }\end{array}$ & +1 & & \\
\hline 3. & $\begin{array}{l}\text { Was there a homoeopathic aggravation of } \\
\text { symptoms? }\end{array}$ & & 0 & \\
\hline 4. & $\begin{array}{l}\text { Did the effect encompass more than the main } \\
\text { symptom or condition (i.e. were other symp- } \\
\text { toms, not related to the main presenting } \\
\text { complaint, improved or changed)? }\end{array}$ & +1 & & \\
\hline 5. & $\begin{array}{l}\text { Did overall well-being improve? (Suggest using } \\
\text { a validated scale or mention about changes in } \\
\text { physical, emotional and behavioural elements) }\end{array}$ & +1 & & \\
\hline $6 \mathrm{~A}$. & $\begin{array}{l}\text { Direction of cure: did some symptoms improve } \\
\text { in the opposite order of the development of } \\
\text { symptoms of the disease? }\end{array}$ & & & 0 \\
\hline $6 B$. & $\begin{array}{l}\text { Direction of cure: did at least one of the } \\
\text { following aspects apply to the order of im- } \\
\text { provement in symptoms: } \\
\text { - From organs of more importance to those } \\
\text { of less importance? } \\
\text { - From deeper to more superficial aspects of } \\
\text { the individual? } \\
\text { - From the top downwards? }\end{array}$ & +1 & & \\
\hline 7. & $\begin{array}{l}\text { Did 'old symptoms' (defined as non-seasonal } \\
\text { and non-cyclical symptoms that were previ- } \\
\text { ously thought to have resolved) reappear } \\
\text { temporarily during the course of } \\
\text { improvement? }\end{array}$ & & 0 & \\
\hline 8. & $\begin{array}{l}\text { Are there alternative causes (i.e. other than the } \\
\text { medicine) that-with a high probability-could } \\
\text { have produced the improvement? (Consider } \\
\text { known course of disease, other forms of } \\
\text { treatment and other clinically relevant } \\
\text { interventions) }\end{array}$ & & +1 & \\
\hline 9. & $\begin{array}{l}\text { Was the health improvement confirmed by any } \\
\text { objective evidence? } \\
\text { (e.g. investigations, clinical examination) }\end{array}$ & +2 & & \\
\hline 10. & $\begin{array}{l}\text { Did repeat dosing, if conducted, create similar } \\
\text { clinical improvement? }\end{array}$ & & & 0 \\
\hline
\end{tabular}

\section{Conclusion}

The presented case report is a rare case of PT. Homoeopathic treatment was found useful in treating the case.

\section{Author Contributions}

P.S.: concept, literature search, clinical study and preparation of the article; P.M.: about the present modern medicine intervention, drafting the paper; R.K.M.: expert opinion regarding pathological investigation; R.K.J.: ultrasonological examination and expert opinion; all the authors reviewed and approved the final paper.

\section{Funding}

The project was funded under the Extra-Mural Research Scheme of Ministry of Ayurveda, Yoga \& Naturopathy, Unani, Siddha and Homoeopathy, Government of India (vide letter no F. No-23-111/2009-10/CCRH/Tech/EMR/ 8758 dated 7th September 2009). Technical and administrative support was provided by the Central Council for Research in Homoeopathy.

Conflict of Interest

None of the authors have a conflict of interest in respect to the present work.

\section{References}

1 McCarthy E, Kavanagh J, O'Donoghue Y, McCormack E, D'Arcy C, O'Keeffe SA. Phyllodes tumours of the breast: radiological presentation, management and follow-up. Br J Radiol 2014;87(1044):20140239

2 Das S. A Concise Textbook of Surgery. 5th ed. Kolkata. Published by Dr. Somen Das; 2009:710

3 Calhoun K, Lawton TJ, Kim JM, et al. Phyllodes tumour. In: Harris J, Lippman ME, Osborne CK, Morrow M, eds. Diseases of the Breast. Philadelphia: Lippincott Williams and Wilkins; 2010:781 
4 Chaney AW, Pollack A, McNeese MD, et al. Primary treatment of cystosarcoma phyllodes of the breast. Cancer 2000;89(07): 1502-1511

5 Rowell MD, Perry RR, Hsiu JG, Barranco SC. Phyllodes tumors. Am J Surg 1993;165(03):376-379

6 Bernstein L, Deapen D, Ross RK. The descriptive epidemiology of malignant cystosarcoma phyllodes tumors of the breast. Cancer 1993;71(10):3020-3024

7 Birch JM, Alston RD, McNally RJ, et al. Relative frequency and morphology of cancers in carriers of germline TP53 mutations. Oncogene 2001;20(34):4621-4628

8 Ward ST, Jewkes AJ, Jones BG, et al. The sensitivity of needle core biopsy in combination with other investigations for the diagnosis of phyllodes tumours of the breast. Int J Surg 2012;10(09):527-531

9 Shukla P, Misra P, Misra RK, et al. Homoeopathic management of breast fibroadenoma - an open label, single arm, observational trial. Homoeopathic Links 2020;33(02):90-98

10 Lamba CD, Gupta VK, van Haselen R, et al. Evaluation of the Modified Naranjo Criteria for assessing causal attribution of clinical outcome to homeopathic intervention as presented in case reports. Homeopathy: the Journal of the Faculty of Homeopathy 2020. Doi: $10.1055 / \mathrm{s}-0040-1701251$

11 RADAR $\circledast$, version 10.0.028 (ck), Archibel 2007, Belgium

12 Kent JT. Lectures on Homoeopathic Materia Medica. New Delhi: B. Jain Publishers; 2006:467-473

13 Boericke William. Pocket Manual of Homoeopathic Materia Medica and Repertory. New Delhi: B. Jain Publishers; 2008:230-232

14 Park HJ, Ryu HS, Kim K, Shin KH, Han W, Noh DY. Risk factors for recurrence of malignant Phyllodes tumors of the breast. In Vivo 2019;33(01):263-269
15 Kent JT. Lectures on Homoeopathic Philosophy. New Delhi: Indian Books \& Periodicals Publishers; 2007:10

16 Hahnemann S. Organon of Medicine. 6th edition. New Delhi: B. Jain Publishers (P) Ltd; 2002:103

17 den Exter PL, Hornstra BJ, Vree R. [Phyllodes tumour: a rare, rapidly growing breast tumour]. Ned Tijdschr Geneeskd 2009; 153:A981

18 Yan Z, Gudi M, Lim SH. A large benign phyllodes tumour of the breast: a case report and literature review. Int J Surg Case Rep 2017;39:192-195

19 Barth RJ Jr, Wells WA, Mitchell SE, Cole BF. A prospective, multiinstitutional study of adjuvant radiotherapy after resection of malignant phyllodes tumors. Ann Surg Oncol 2009;16(08): 2288-2294

20 Spanheimer PM, Murray MP, Zabor EC, et al. Long-term outcomes after surgical treatment of malignant/borderline phyllodes tumors of the breast. Ann Surg Oncol 2019;26(07): 2136-2143

21 Burnett JC. Tumours of the Breast and Their Treatment and Cure by Medicines. New Delhi: B. Jain Publishers (P) Ltd; 2005:84-86

22 Burnett JC. Curability of Tumours by Medicines. New Delhi: B. Jain Publishers (P). Ltd.; 2014;191:255

23 Tanwar P, Gupta S, Bharti D, Kalra D, Kumar N, Sodha VS Magnitude of hypothyroidism in benign breast disorders and effect of thyroxin replacement on clinical outcome of benign breast disorders with hypothyroidism as co morbidity. International Journal of Research in Health Sciences 2016;6(06):61-70

24 Cerrag X. Breast fibroadenoma and uterine fibroid in a female with HACEK endocarditis: is there any possible correlation? J Womens Health Care 2015;4(08):1000287 